\title{
Serosurvey of anti-Toxoplasma gondii antibodies in homeless persons of São Paulo city, southeastern Brazil
}

\author{
Laís Giuliani Felipetto \\ Federal University of Parana \\ Pedro Irineu Teider-Junior \\ Federal University of Parana \\ Felipe Fortino Verdan da Silva \\ Federal University of Parana \\ Ana Carolina Yamakawa \\ São Paulo State University \\ Louise Bach Kmetiuk \\ Federal University of Parana \\ Anahi Chechia do Couto \\ Federal University of Parana \\ Camila Marinelli Martins \\ Ponta Grossa State University \\ Eduarda Stankiwich Vaz \\ Federal University of Parana \\ Leila Sabrina Ullmann \\ São Paulo State University \\ Helio Langoni \\ São Paulo State University \\ Jorge Timenetsky \\ São Paulo University \\ Andrea Pires dos Santos \\ Purdue University
}

Alexander Weilker Biondo ( $\square$ abiondo@ufpr.br)

Federal University of Paraná https://orcid.org/0000-0002-4182-5821

Research article

Keywords: homeless, Toxoplasma gondii, HIV, vulnerability

Posted Date: May 8th, 2020

DOI: https://doi.org/10.21203/rs.2.22570/v2

License: (9) (1) This work is licensed under a Creative Commons Attribution 4.0 International License. Read Full License 


\section{Abstract}

Background: Seroprevalence of Toxoplasma gondii has been extensively studied in a variety of vulnerable populations. However, no study has focused on homeless populations. Accordingly, the present study aimed to assess the seroprevalence of anti- $T$. gondii antibodies and the risk factors associated in homeless persons from homeless shelter of São Paulo city, southeastern Brazil. In addition, anti-HIV antibodies and associated risk of T. gondii and HIV coinfection have been evaluated.

Methods: Anti-T. gondii antibodies were detected by indirect fluorescent antibody test. In addition, anti-HIV levels were testedby chemiluminescence enzyme immunoassay, with positive samples confirmed by rapid immunoblot assay.

Results: Overall, IgG anti-T. gondii seropositivity was found in 43/120 (35.8\%) homeless persons, with endpoint titers varying from 16 to 1,024 . The only two pregnant womentested were negative for IgM by chemiluminescence enzyme immunoassay, with normal parturition and clinically healthy newborns in both cases. There were no statistical differences in the risk factors for anti- $T$. gondii serology ( $p>0.05)$. Anti-HIV seropositivity was found in $2 / 120(1.7 \%)$ homeless persons, confirmed as HIV-1. One HIV seropositive individual was also sero-reactive to IgG anti-T.gondii, and both were negative to IgM anti-T. gondii.

Conclusions: This is the first study that reports the serosurvey of $T$. gondii in homeless persons worldwide. Despite the limited sample size available in the present study, our findings have shown that the prevalence of anti-T. gondii antibodies in homeless persons herein was lower than the general population, probably due to homeless diet habit of eating mainly processed food intake. No statistical differences were found regarding risk factors for anti-T. gondii exposure in homeless persons.

\section{Background}

Homeless persons have been described as one of the three most vulnerable populations, along with refugees and incarcerated persons [1]. Morbidity and mortality of diseases have been reportedly higher in homeless than general population, probably due to social inequality associated with lack of settled home, job opportunity, and a series of family problems including drug addiction, mental health disorders, and social justice issues, mostly exacerbated by absence of health assistance [2]. A population of 1.6 billion peoplewithout adequate housing has been estimated worldwide, of which 100 million are homeless [3, 4]. In Brazil, the nationwide homeless population has been estimated in 101,854 individuals, with about $40.1 \%$ living in cities with more than 900,000 inhabitants and about 16,000 living on streets of São Paulo city $[5,6]$.

Toxoplasma gondii is a coccidian parasite relying on cats and other Felidae as definitive hosts, which may shed fecal oocysts infecting a variety of homeothermic intermediate hosts [7]. Human infection has been typically subclinical or asymptomatic, with the time of infection and transmission route not known in most cases [8, 9]. Despite that, in immunodeficient people, such as in HIV-toxoplasmosis combination, the protozoan can cause severe clinical manifestations, with invasion into the central nervous system and encephalitis $[10,11]$.

Although human $T$. gondii seroprevalence has been extensively reported, ranging from $0.8 \%$ to $77.5 \%$ worldwide [12], few reports are available for vulnerable populations including 123/597 (20.6\%) aboriginal individuals of Thailand, 236/628 (37.6\%) prisoners of Turkey, mostly (92.8\%) males, and 63/199 (31.7\%) pregnant refugee and borderline migrant women of Asia [13-15]. In Brazil, seropositivity of $T$. gondii has been ranged from 14/65 (21.5\%) urban students of northeastern region to 113/116 (97.4\%) farmers of dairy cattle farm in central-western region $[16,17]$. In vulnerable populations of Brazil, the positivity reported was 131/231 (56.7\%) inhabitants living in riverside communities of northern region and 119/148 (80.4\%) indigenous of central-western region $[18,19]$.

Although $T$. gondii seroprevalence has been reported in a variety of vulnerable populations, no study has focused on homeless populations. Accordingly, the present study aimed to assess the seroprevalence of anti-T. gondii and the associated risk factors for exposure in homeless persons from homeless shelter ofSão Paulo city, southeastern Brazil. In addition, anti-HIV antibodies and associated risk of $T$. gondii and HIV coinfection have been evaluated.

\section{Material And Methods}


The present study represents a descriptive cross-sectional seroepidemiological approach of the homeless population from the western São Paulo city ( $23^{\circ} 33^{\prime} 1$ 'S, $\left.46^{\circ} 38^{\prime} 2^{\prime \prime} W\right)$ shelter (Social Center "Our Lady of Good Delivery"), responsible for daytime attendance of all the city region. Theshelter isa Non-Governmental Organization (NGO), sponsored by acity partnership daily attending around 800 to 1,200 homeless persons, providing meals, medical assistance, job opportunities, and recreational activities.

São Paulo city, capital of São Paulo State, southeastern Brazil, has been ranked as the most populated city of Latin America with $11,253,500$ people and the tenth-largest Gross Domestic Product (GDP) of the world, with a very high Human Development Index (HDI) (0.805). The city is located under a humid subtropical climate with average temperatures ranging from $19{ }^{\circ} \mathrm{C}$ (winter) to 25 ${ }^{\circ} \mathrm{C}$ (summer) [20].

The present study was conducted along with the city multi-task professionals team at the São Paulo City Secretary of Health, called "street outreach office", which includes physicians, nurses, dentists, social assistants, and psychologists, based on the strategy of the Brazilian Unified Health System [21]. This city official team offers permanent assistance and save clinical records of the homeless population, promoting health actions on a continuing care bond.

\section{Epidemiological data collection}

Epidemiological analyses were performed based on a questionnaire associated with homeless personsexposure to T.gondii and HIV, which included: 1) Demographic profile: sex, marital status, racial self-declaration, age, educational background, income, and city of origin; 2) Social profile: travel to other cities, communication with family, causes for becoming homeless, homelessness time, resting place, have children, have own children, pregnant woman, live alone, pet owner, use of licit and illicit drugs, alcohol consumption, tobacco use, marijuana use, cocaine use, crack use, assistance by the Psychosocial Care Centers (CAPS) as part of the free national Unified Health System; 3) Hygiene profile: bath frequency, change of clothes frequency, wash clothes, body lice (Pediculus humanus humanus) bites, and body lice presence (S1 Dataset). Refusal to fully or partially answer any questionor incomplete answers were accepted and registered.

\section{Sample collection}

A minimal sampling of 71 individuals was calculated using commercially available software (Epi Info 7.7.7.6) based on an estimative of 16,000 homeless persons in São Paulo City and homeless HIV infection prevalence of 4.9\% [22], the sampling was simple with $95 \%$ confidence and $5 \%$ accuracy. Blood samples of homeless persons were conveniently collected in São Paulo city from June to August 2018. Homeless persons were recruited by government health officials and invited to participate voluntarily of research, and blood collection was performed by cephalic puncture. Samples were placed in tubes without anticoagulant and kept at $25^{\circ} \mathrm{C}$ until visible clot retraction. Serum was separated by centrifugation at 3,000 revolutions per minute for 10 minutes and stored at $-20^{\circ} \mathrm{C}$ until processing.

In addition, the packed cell volume (PCV) by capillary tube centrifugation and total plasma protein (TPP) by refractometry were performed on the day of sampling and immediately given to the shelter administration. Due to the shelter demand, homeless persons were also examined for body lice (Pediculus humanus humanus) bites and presence, as previously described at the same shelter [23]. The University made a clothing donation drive during the study and researchers offered clean clothes to all liceinfested homeless persons.

\section{Serological diagnosis}

Detection of T. gondii antibodies was performedby indirect immunofluorescent antibody test (IFAT) [24], with serial serum dilutions of 1:16 to 1:4,096 performed in $\mathrm{pH} 7.2$ phosphate-buffered saline solution (PBS) with the cut-off titer of $\geq 16$ IU. Immunofluorescence slides were previously sensitized with $0.1 \%$ formaldehyde to inactivated tachyzoites of $T$. gondii (RH strain) obtained from an intraperitoneal lavage in Swiss mice after three days of inoculation. A commercial anti-human IgG antibody, 
conjugated with fluorescein isothiocyanate (Bethyl Laboratories, Montgomery, TX, USA) was used as secondary antibody. For positive samples, the highest titer was considered with at least $50 \%$ of fluorescence on the border of tachyzoites.

In addition, the detection of HIV was performed by chemiluminescent microparticle immunoassay (CMIA) (Alinity'sHIV Ag/Ab Combo Reagent Kit, Abbott Laboratories, Chicago, IL, USA) used for the simultaneous qualitative detection of HIV p24 antigen and antibodies to HIV type 1 (HIV-1 group M and group 0) and/or type 2 (HIV-2) in human serum. The resulting chemiluminescent reaction was measured as relative light units (RLU). Samples of the pregnant woman and the HIV-positive individuals weretested for T. gondii IgM presence by CMIA (Anility's Toxo IgM Reagent Kit, Abbott Laboratories, Chicago, IL, USA).

\section{Statistical analysis}

Statistical analysis was performed using SPSS 20.0 [25]. Frequencies of T.gondii and HIV seropositivity (absolute and relative) were determined by the stratification of the observations according to demographic, social, and hygiene profiles. The Chi-Square test was used to determine the bivariate association between studied variables, and odds ratios (OR) were used for the association of T. gondii prevalence and potential risk factors.

\section{Ethics approval and consent to participate}

This study was approved by the Ethics Committee in Human Research at the Federal University of Paraná (CAAE: 80099017.3.0000.0102, protocol number: 2.512.196), by the Ethics in Human Health Committee at the São Paulo City Secretary of Health (CAAE: 80099017.3.3004.0086, protocol number: 3.366.684) and by Ethics Committee in Human Research of the Clinics Hospital at the Federal University of Paraná (CAAE: 80099017.3.3005.0096, protocol number: 3.623.845), all subordinate to the National Human Ethics Research Committee of the Brazilian Ministry of Health. The Informed Consent Form was applied to all homeless persons, according to the ethical guidelines and principles of Federal University of Paraná. All participants research provided written informed consent.

\section{Results}

Overall, anti-T.gondii antibodies were detected in 43/120 (35.8\%, Cl 95\% 26,7-43,0\%) homeless persons, with endpoint titers varying from 16 to 1,024 . No statistical differences were found regarding risk factors for anti-T. gondii exposure $(p>0.05)$ in homeless persons (Table 1).

Associated risk factors forthe presence of anti-T. gondii were not statistically significant regarding educational background $(p=0.438)$, income $(p=0.805)$, resting place (hostels, street, occupancy) ( $>0.05)$, pregnancy $(p=0.567)$, pet owner $(p=0.399)$; cat owner $(p=0.916)$, bath frequency $(p=0.652)$, age $(p=0.223)$, and homelessness time $(p=0.827)$ (Table 2$)$. The homeless persons sampled were mostly men counting 107/120 (89.2\%) individuals, with 39/107 (36.8\%) seropositive samples for T. gondii. On the other side, women accounted for 13/120 (10.8\%) with 3/13 (23.1\%) positive samples. Despite in lower number, eight women were within the reproductive age of 24 to 35 years old, and $7 / 8$ (87.5\%) presented negative serology for $T$. gondii, including the two pregnant homeless women exposed to infection. Fortunately, the two pregnant women tested negative for anti-T. gondii antibodies in both IgG by IFAT and IgM by CMIA, with normal parturition and clinically healthy newborns in both cases.

In addition, a total of 2/120 (1.7\%, CI 95\% 0.0-4.2\%) anti-HIV seropositive homeless persons were detected by CMIA and confirmed by rapid immunoblot assay tests. No evaluation of HIV risk factors was made due to low seropositive rate.

\section{Discussion}

To the authors' knowledge, this is the first study that reports the serosurvey of $T$. gondii in homeless persons and the associated risk factors.

The seroprevalence of anti- T. gondii antibodies herein (35.8\%) was higher than other vulnerable populations, such as aborigines (20.6\%) and pregnant refugee and borderline migrant women (31.7\%) but similar to incarcerated populations (37.6\%) [13-15]. In Brazil, the anti-T. gondii seroprevalence herein was higher than the general population of the northeastern region, with 14/65 
(21.5\%) seropositive urban students, but lower than the central-western region, with 113/116 (97.4\%) farmers from a single dairy cattle farm with domestic cats and potentially contaminated environment $[16,17]$. Interestingly, the seroprevalence of anti- $T$. gondii antibodies in the present study was lower than other Brazilian neglected populations, such as 131/231 (56.7\%) persons of riverside communities in the northern and 119/148 (80.4\%) indigenous persons in the central-western region [18, 19]. In São Paulo, similar results were found, with 110/339 (32.4\%) seropositive children from a low-socioeconomic community [26]. Not surprisingly, a previous study has shown an association between high seropositivity for T. gondii and socioeconomic vulnerability in southern Brazil, with 526/715 (73.57\%) seropositive individuals, particularly in low-income families [27].

Although low education and socioeconomic status have been associated with increased risk of $T$. gondii infection in different Brazilian studies [28-30], no statistical association with T. gondii infection was previously found regarding educational background and income,probably due to the broadly variable classification of and the low population homogeneity [31, 32]. Similarly, no association was found in either education or income, likely associated to the impact of the vulnerable living style, with mostly drug addicts with poor eating habits.

Since the low socioeconomic status may be associated to malnutrition and might impair the host defense against protozoan infection, the relatively low seroprevalence of anti- $T$. gondii antibodies in homeless herein may be consequence of mainly consumption of ready-to-eat foods, as already indicated by previous studies on homelessness and food preparation facilities, which have reported dependence on charity meals such as pre-prepared foods, processed foods or popular snacks [33-36]. Not surprisingly, pre-processed ready-to-eat and meat-based foods have been shown to inactivate T. gondii cysts [37].

In addition, healthier and more expensive items such as meat, fish, vegetables, and fruits have been less often consumed by homeless [33, 36, 38, 39], which may bea contributing factor to the low $T$. gondii seroprevalence found in this study. Hence, it is reasonable to speculate that the beneficial shelters, hostels, and meal services may have offered protection to the homeless population $[36,40]$ but not as nutritional good food habits when compared to the general population. Although no homeless person has been diagnosed with either anemia by packed cell volume (PCV) or hypoproteinemia by refractometry, such tests may not have enough sensitivity to detect chronic alimentary deficiencies, which should be further investigated.

A previous study with pregnant women has shown high seroprevalence of specific anti-T. gondii antibodies (68.4\%; 333/487) and vertical transmission associated with social vulnerability in central Brazil [41]. In the present study, despite negative for both IgG and IgM anti-T. gondii antibodies, the two pregnant women sampled, fortunately,gave birth to clinically healthy babies. T. gondii infection during pregnancy has been a significant problem, especially during the first months, and may result in spontaneous abortion, fetal and/or neonatal death or several congenital disabilities such as hydrocephalus, central nervous system disorders, and chorioretinitis $[42,43]$. In the second and third trimester, newborns have usually been asymptomatic, with symptoms appearing late in childhood or early in adulthood, and may sporadically cause visual impairment [42, 44, 45]. In addition, congenital toxoplasmosis may also be associated with reactivation of the chronical maternal infection, particularly in HIVinfected and immunosuppressed women [46]. As 7/8 (87.5\%) women herein were within reproductive age and presented negative serology for $T$. gondii, the homeless may be highly unprotected to infection duringpregnancy.

Although the present study has shown no association between $T$. gondii infection and pet ownership, including stray cat owners, corroborating with previous studies in rural and other vulnerable populations of southern Brazil [27, 31], only $6 / 120(0.5 \%)$ homeless personsowned a total of 11 cats. Outdoor lifestyle of stray cats may include hunting of birds and rodents, leading to raw meat dietary habits and increased risk of $T$. gondii ingestion [47]. Nonetheless, human toxoplasmosis outbreaks may be attributed to exposure to infected cats, which may indicate an important role of cat oocyst excretion on infection spreading [48, 49], and homeless might be daily overexposed to environmental contamination. However, as mentioned above, homeless dietary habits of high intake of processed foods and low fresh meat, fish, vegetables and fruits may have led to lower T. gondii exposure.

Body lice (Pediculus humanus humanus) has been recently considered as a reemerging problem among homeless populations in France, Italy, USA, Colombia, and Brazil [23, 50-53]. Even though body lice presence suggests social vulnerability and 17/120 (14.2\%) of the homeless herein were infested with lice, no statistically risk of $T$. gondii exposure was found. 
In addition to the T. gondii serosurvey, the HIV seroprevalence has been assessed herein. In the present study, 2/120 (1.7\%) homeless persons was positive to anti-HIV antibodies, above the estimated prevalence of $0.4 \%$ for the general Brazilian population and lower than a recent study with 69/1,402 (4.9\%) seropositive homeless. Despite previous studies have shown a high prevalence of $T$. gondii and HIV co-infection, with $35.8 \%$ worldwide in a meta-analysis study and up to $88.4 \%$ of individuals coinfected in Ethiopia [54,55], the analysis of associated risk factors herein has been impaired due to low HIV positive frequency.

Another limitation of the present study has surveyed low number of individuals, which has generated insufficient data to provide robust statistical description and analyses. However, mostly due to difficulties in accessing homeless and their refusal to participate, no study to date has been performed in toxoplasmosis and associated risk factors. In addition, questionnaires to assess homeless information may be problematic, particularly regarding food intake and dietary habits, once such a population has often shown a chaotic lifestyle and a high prevalence of drug use and mental health disorders [36].

Finally, further studies should be conducted in higher number and different homeless populations to fully establish the exactly impact of $T$. gondii in homeless persons worldwide.

\section{Conclusions}

In conclusion, this is the first study that reports the serosurvey of $T$. gondii in homeless persons worldwide. Despite the limited sample size available in the present study, our findings have shown that the prevalence of anti-T. gondii antibodies in homeless persons herein was lower than the general population, probably due to homeless diet habit of eating mainly processed food intake. No statistical differences were found regarding risk factors for anti-T. gondii exposure in homeless persons.

\section{List Of Abbreviations}

CAPS: Psychosocial Care Centers; CMIA: chemiluminescent microparticle immunoassay; GDP: Gross Domestic Product; HDI: Human Development Index; HIV: Human immunodeficiency virus; IFAT: immunofluorescent antibody test; NGO: NonGovernmental Organization; PBS: phosphate-buffered saline solution; PCV: packed cell volume; RLU: relative light units; OR: odds ratios; SD: standard deviation; TPP: total plasma protein.

\section{Declarations}

\section{Acknowledgments}

This research has been partially supported by the Veterinary Science Graduate Program at Federal University of Paraná, Clinical Analysis Laboratory Unit, Clinics Hospital (UFPR), Institute of Biotechnology (UNESP), Department of Veterinary Hygiene and Public Health (UNESP), and Purdue University. The authors are thankful to Dr. Mara Lúcia Gravinatti and the Social Center "Our Lady of Good Delivery" for helping with collection, sampling, and follow-up information.

\section{Authors' Contributions}

Drafting and revision of the manuscript: LGF, PIT-Jr, ACY, LBK, CMM, LSU, AWB. Initiation, conception, design and coordination of the research project: LGF, LSU, HL, JT, APS, AWB. Development of the intervention and evaluation materials: LGF, FFVS, ACC, CMM, ESV. Implementation of the intervention: LGF, PIT-Jr, LBK, CMM, LSU, APS, AWB. All authors read and approved the final version of the manuscript.

\section{Funding}

MSc Felipetto has been supported by a PhD fellowship and research funding from Capes DS through the Graduate College of Veterinary Science, Federal University of Paraná (UFPR).

\section{Availability of data and materials}

All data generated or analysed during this study are included in this published article [and its supplementary information files]. 


\section{Consent for publication}

Not applicable.

\section{Competing interests}

The authors have declared that no competing interests exist.

\section{Author details}

${ }^{1}$ Departament of Veterinary Science, Federal University of Paraná (UFPR), Curitiba, Paraná (PR), 80035-050, Brazil. ${ }^{2}$ Clinical Analysis Laboratory Unit, Clinics Hospital, Federal University of Paraná (UFPR), Curitiba, Paraná (PR), 80060-900, Brazil.

${ }^{3}$ Department of Veterinary Hygiene and Public Health, São Paulo State University (UNESP), Botucatu, São Paulo (SP), 18618-681, Brazil. ${ }^{4}$ Departament of Cellular and Molecular Biology, Federal University of Paraná (UFPR), Curitiba (PR), 81531-970, Brazil. ${ }^{5}$ Department of Nursing and Public Health, State University of Ponta Grossa, Ponta Grossa (UEPG), Paraná (PR), $84030-$ 900, Brazil, and AAC\&T Research Consulting LTDA, Curitiba, Paraná (PR), 82540-096, Brazil. ${ }^{6}$ Institute of Biotechnology, São Paulo State University (UNESP), Botucatu, São Paulo (SP), 18607-440, Brazil. ${ }^{7}$ Department of Medical Microbiology, University of São Paulo (USP), São Paulo, São Paulo (SP), 05508-900, Brazil. ${ }^{8}$ Department of Comparative Pathobiology, Purdue University (PU), West Lafayette, Indiana (IN), 47907-2073, USA.

\section{References}

1. Aldridge RW, Story A, Hwang SW, Nordentoft M, Luchenski SA, Hartwell G, et al. Morbidity and mortality in homeless individuals, prisoners, sex workers, and individuals with substance use disorders in high-income countries: a systematic review and meta-analysis. Lancet. 2018;391(10117):241-50. doi:10.1016/s0140-6736(17)31869-x.

2. Fazel S, Geddes JR, Kushel M. The health of homeless people in high-income countries: descriptive epidemiology, health consequences, and clinical and policy recommendations. Lancet. 2014;384(9953):1529-40. doi:10.1016/S01406736(14)61132-6.

3. United Nations Organization. Commission on Human Rights. Economic, Social and Cultural Rights. Report of the Special Rapporteur on adequate housing as a component of the right. to an adequate standard of living, Miloon Kothari. 2005. https://documents-dds-ny.un.org/doc/UNDOC/GEN/G05/117/55/PDF/G0511755.pdf?OpenElement.Accessed 20 Dec 2019.

4. United Nations Organization. Expert Group Meeting. Affordable Housing and Social Protection Systems for All to Address Homelessness. Department of Economic and Social Affairs. https://www.un.org/development/desa/dspd/wpcontent/uploads/sites/22/2019/10/summary-egm-final-9sep.pdf.Accessed 20 Dec 2019.

5. Institute of Economic Research Foundation. Pesquisa Censitária da População em Situação de Rua, Caracterização Socioeconômica da População Adulta em Situação de Rua e Relatório Temático de Identificação das Necessidades desta População na Cidade de São Paulo. 2015. https://www.prefeitura.sp.gov.br/cidade/secretarias/upload/00publicacao_de_editais/0005.pdf. Accessed 10 Dec 2007.

6. Institute for Applied Economic Research. Atlas de Vulnerabilidade Social dos Municípios Brasileiros. http://ivs.ipea.gov.br/images/publicacoes/lvs/publicacao_atlas_ivs.pdf.Accessed 14 Sept. 2007.

7. Hill DE, Dubey JP. Toxoplasma gondii. Biology of Foodborne Parasites. CRC Press. 2015;209-222 pp.

8. Hill D, Dubey JP. Toxoplasma gondii: transmission, diagnosis and prevention. Clin Microbiol Infect. 2002;8(10):634-40. doi: 10.1046/j.1469-0691.2002.00485.x.

9. Petersen E, Vesco G, Villari S, Buffolano W. What do we know about risk factors for infection in humans with Toxoplasma gondii and how can we prevent infections?. Zoonoses Public Health. 2010;57(1):8-17. doi: 10.1111/j.1863-

2378.2009.01278.x.

10. Deeks SG, Overbaugh J, Phillips A, Buchbinder S. HIV infection. Nat Rev Dis Primers. 20151;1:15035. doi: 10.1038/nrdp.2015.35. 
11. Cong W, Dong XY, Meng QF, Zhou N, Wang XY, Huang SY, et al. Toxoplasma gondii infection in pregnant women: A seroprevalence and case-control study in Eastern China. Biomed Res Int. 2015;2015:170278. doi: 10.1155/2015/170278.

12. Pappas G, Roussos N, Falagas ME. Toxoplasmosis snapshots: global status of Toxoplasma gondii seroprevalence and implications for pregnancy and congenital toxoplasmosis. Int J Parasitol. 2009;39(12):1385-94. doi: 10.1016/j.ijpara.2009.04.003.

13. Fan CK, Liao CW, Wu MS, Su KE, Han BC. Seroepidemiology of Toxoplasma gondii infection among Chinese aboriginal and Han people residing in mountainous areas of northern Thailand. J Parasitol. 2003;89(6):1239-42. doi: 10.1645/GE-3215RN.

14. Yaman O, Yazar S, Çetinkaya Ü, Özcan Temel H, Balci E, Pehlivan İ, et al. Kayseri Kapalı.Cezaevi. Mahkumlarında Toxoplasma gondii Seroprevalansı. Türkiye Parazitol Derg. 2009;33(1):15-9.

15. van Enter BJD, Lau YL, Ling CL, Watthanaworawit W, Sukthana Y, Lee WC, et al. Seroprevalence of Toxoplasma gondii Infection in Refugee and Migrant Pregnant Women along the Thailand-Myanmar Border. Am J Trop Med Hyg. 2017;97(1):232-5. doi:10.4269/ajtmh.16-0999.

16. de Amorim Garcia CA, Oréfice F, de Oliveira Lyra C, Gomes AB, França M, de Amorim Garcia Filho CA. Socioeconomic conditions as determining factors in the prevalence of systemic and ocular toxoplasmosis in Northeastern Brazil. Ophthalmic Epidemiol. 2004;11(4):301-17.

17. Santos GM, Silva SA, Barbosa AP, Campos DM. Investigação soroepidemiológica sobre a larva migrans visceral por Toxocara canis em usuários de serviços de saúde de Goiânia - GO. Ver Patol Trop. 2009;38(3):197-206.

18. Amendoeira MRR, Sobral CAQ, Teva A, Lima JN, Klein CH. Inquérito sorológico para a infecção por Toxoplasma gondii em ameríndios isolados, Mato Grosso. Rev. Soc. Bras. Med. Trop. 2003;36(6):671-6. doi: 10.1590/S0037-86822003000600005.

19. Vitaliano SN, Mendonça GM, Sandres FAM, Camargo JSAA, Tarso P, Basano AS, et al. Epidemiological aspects of Toxoplasma gondii infection in riverside communities in the Southern Brazilian Amazon. Rev. Soc. Bras. Med. Trop. 2015;48(3):301-6. doi: 10.1590/0037-8682-0040-2015.

20. Brazilian Institute of Geography and Statistics. Censo Demográfico 2010: Panorama geral, São Paulo, Brasil. 2010. https://cidades.ibge.gov.br/brasil/sp/sao-paulo/panorama.Accessed 14 Sept. 2019.

21. Paula HC, Daher DV, Koopmans FF, Faria MGA, Brandão PS, Scoralick GBF. Implementation of the Street Outreach Office in the perspective of health care. Revista Brasileira de Enfermagem. 2018;71(6):2843-7. doi: 1590/0034-7167-2017-0616.

22. Grangeiro A, Holcman MM, Onaga ET, Alencar HDR, Placco ALN, Teixeira PR. Prevalência e vulnerabilidade à infecção pelo HIV de moradores de rua em São Paulo, SP. Rev. Saúde Públ. 2012;46(4):674-84. doi: 10.1590/S0034-89102012005000037.

23. Gravinatti ML, Faccini-Martínez ÁA, Ruys SR, Timenetsky J, Biondo AW. Preliminary report of body lice infesting homeless people in Brazil. Rev Inst Med Trop S. Paulo. 2018;60:e9. doi: 10.1590/s1678-9946201860009.

24. Camargo ME. Introdução às técnicas de imunofluorescência. Rev. Bras. Patol. Clín. 1974;10(3):143-69.

25. IBM Corp. Released in 20 IBM SPSS Statistics for Windows, Version 21.0. Armonk, NY: IBM Corp.

26. Francisco FM, Souza SLP, Gennari SM, Pinheiro SR, Muradian V, Soares RM. Seroprevalence of toxoplasmosis in a lowincome community in the São Paulo municipality, SP, Brazil. Rev. Inst. Med. trop. S. Paulo. 2006;48(3):167-70. doi: 10.1590/S0036-46652006000300009.

27. Mareze M, Benitez ADN, Brandão APD, Pinto-Ferreira F, Miura AC, Martins FDC, et al. Socioeconomic vulnerability associated to Toxoplasma gondii exposure in southern Brazil. PLoS One. 2019;14(2):e0212375. doi: 10.1371/journal.pne.0212375.

28. Bahia-Oliveira LM, Jones JL, Azevedo-Silva J, Alves CC, Oréfice F, Addiss DG. Highly endemic, waterborne toxoplasmosis in north Rio de Janeiro state, Brazil. Emerg Infect Dis. 2003;9(1):55-62. doi: 10.3201/eid0901.020160.

29. Avelino MM, Campos D Jr, Parada JB, Castro AM. Risk factors for Toxoplasma gondii infection in women of childbearing age. Braz J Infect Dis. 2004;8(2):164-74. doi: 10.1590/s1413-86702004000200007.

30. Lopes-Mori FM, Mitsuka-Breganó R, Bittencourt LHFB, Dias RCF, Gonçalves DD, Capobiango JD, et al. Gestational toxoplasmosis in Paraná State, Brazil: prevalence of IgG antibodies and associated risk factors. Braz J Infect Dis. 2013;17(4):405-9. doi: 10.1016/j.bjid.2012.12.003.

31. Araújo AC, Villela MM, Sena-Lopes Â, Farias NAR, Faria LMJ, Avila LFC, et al. Seroprevalence of Toxoplasma gondii and Toxocara canis in a human rural population of Southern Rio Grande do Sul. Rev. Inst. Med. Trop. S. Paulo. 2018;60:e28. doi: 
10.1590/S1678-9946201860028.

32. Passos ADC, Bollela VR, Furtado JMF, Lucena MM, Bellissimo-Rodrigues F, Paula JS, et al. Prevalence and risk factors of toxoplasmosis among adults in a small Brazilian city. Rev. Soc. Bras. Med. Trop. 2018;51(6):781-7. doi: 10.1590/0037-86820214-2017.

33. Hickey C, Downey D. Hungry for Change: Social Exclusion, Food Poverty and Homelessness in Dublin. Dublin: Focus Ireland. 2003; 133pp.

34. Food Standards Agency. Research into food poverty and homelessness in Northern Ireland - final report. Belfast: Deloitte MCS Limited. 2006.

http://webarchive.nationalarchives.gov.uk/20111206074236/http://www.food.gov.uk/multimedia/pdfs/homelessnifood.pdf. Accessed 20 Dec 2019.

35. Alvarado-Esquivel C, Torres-Castorena A, Liesenfeld O, Estrada-Martínez S, Urbina-Álvarez JD. High seroprevalence of Toxoplasma gondii infection in a subset of Mexican patients with work accidents and low socioeconomic status. Parasit Vectors. 2012;5:13. doi: 10.1186/1756-3305-5-13.

36. Sprake EF, Russell JM, Barker ME. Food choice and nutrient intake amongst homeless people. J Hum Nutr Diet. 2014;27(3):242-50. doi: 10.1111/jhn.12130.

37. Mie T, Pointon AM, Hamilton DR, Kiermeier A. A qualitative assessment of Toxoplasma gondii risk in ready-to-eat smallgoods processing. J Food Prot. 2008;71(7):1442-52. doi: 10.4315/0362-028x-71.7.1442.

38. Rushton CM, Wheeler IE. The dietary intake of homeless males sleeping rough in Central London. J Hum Nutr Diet. 1993;6(5):443-56. doi: 10.1111/j.1365-277X.1993.tb00389.x.

39. Fallaize R, Seale JV, Mortin C, Armstrong L, Lovegrove JA. Dietary intake, nutritional status and mental wellbeing of homeless adults in Reading, UK. Br J Nutr. 2017;118(9):707-14. doi: 10.1017/S0007114517002495.

40. Li A, Dachner N, Tarasuk V. Food intake patterns of homeless youth in Toronto. Can J Public Health. 2009;100(1):36-40.

41. Gontijo da Silva M, Clare Vinaud M, de Castro AM. Prevalence of toxoplasmosis in pregnant women and vertical transmission of Toxoplasma gondii in patients from basic units of health from Gurupi, Tocantins, Brazil, from 2012 to 2014. PLoS One. 2015;10(11):e0141700. doi: 10.1371/journal.pone.0141700.

42. Kieffer F, Wallon M. Congenital toxoplasmosis. Handb Clin Neurol. 2013;112:1099-101. doi: 10.1016/B978-0-444-529107.00028-3.

43. Abamecha F, Awel H. Seroprevalence and risk factors of Toxoplasma gondii infection in pregnant women following antenatal care at Mizan Aman General Hospital, Bench Maji Zone (BMZ), Ethiopia. BMC Infect Dis. 2016;16(1):460. doi:

10.1186/s12879-016-1806-6.

44. Montoya JG, Liesenfeld O. Toxoplasmosis. Lancet. 2004;363(9425):1965-76. doi: 10.1016/S0140-6736(04)16412-X.

45. Berrébi A, Assouline $C$, Bessières $M H$, Lathière $M$, Cassaing $S$, Minville $V$, et al. Long-term outcome of children with congenital toxoplasmosis. Am J Obstet Gynecol. 2010;203(6):552.e1-552.e6. doi: https://doi.org/10.1016/j.ajog.2010.06.002.

46. Azevedo KML, Setúbal S, Lopes VGS, Camacho LAB, Oliveira AR. Congenital toxoplasmosis transmitted by human immunodeficiency-virus infected women. Braz J Infect Dis. 2010;14(2):186-9. doi: http://dx.doi.org/10.1590/S141386702010000200014.

47. Ding H, Gao YM, Deng Y, Lamberton PHL, Lu DB. A systematic review and meta-analysis of the seroprevalence of Toxoplasma gondii in cats in mainland China. Parasit Vectors. 2017;10:27. doi: 10.1186/s13071-017-1970-6.

48. Teutsch SM, Juranek DD, Sulzer A, Dubey JP, Sikes RK. Epidemic toxoplasmosis associated with infected cats. N Engl J Med. 1979;300(13):695-9. doi: 10.1056/NEJM197903293001302.

49. Torrey EF, Yolken RH. Toxoplasma oocysts as a public health problem. Trends Parasitol. 2013;29(8):380-4. doi: 10.1016/j.pt.2013.06.001.

50. Bonilla DL, Cole-Porse C, Kjemtrup A, Osikowicz L, Kosoy M. Risk factors for human lice and bartonellosis among the homeless, San Francisco, California, USA. Emerg Infect Dis. 2014;20(10):1645-51. doi: 10.3201/eid2010.131655.

51. Ly TDA, Touré Y, Calloix C, Badiaga S, Raoult D, Tissot-Dupont H, et al. Changing Demographics and Prevalence of Body Lice among Homeless Persons, Marseille, France. Emerg Infect Dis. 2017;23(11):1894-7. doi: 10.3201/eid2311.170516. 
52. Faccini-Martínez ÁA, Márquez AC, Bravo-Estupiñan DM, Calixto OJ, López-Castillo CA, Botero-García CA, et al. Bartonella quintana and Typhus Group Rickettsiae Exposure among Homeless Persons, Bogotá, Colombia. Emerg Infect Dis.

2017;23(11):1876-9. doi: 10.3201/eid2311.170341.

53. Liberato C, Magliano A, Romiti F, Menegon M, Mancini F, Ciervo A, et al. Report of the human body louse (Pediculus humanus) from clothes sold in a market in central Italy. Parasit Vectors. 2019;12(201). doi: 10.1186/s13071-019-3458-z.

54. Wang ZD, Wang SC, Liu HH, Ma HY, Li ZY, Wei F, et al. Prevalence and burden of Toxoplasma gondii infection in HIV-infected people: a systematic review and meta-analysis. Lancet HIV. 2017;4(4):e177-e188. doi: 10.1016/S2352-3018(17)30005-X.

55. Feleke DG, Gebreweld A, Zewde G. Toxoplasmosis in Pregnant Women and HIV/AIDS Patients in Ethiopia: A Systematic Review and Meta-Analysis. J. Parasitol. Res. 2019;2019(Article ID 4670397):8pages. doi: 10.1155/2019/4670397.

\section{Tables}

Table 1: Statistical results of univariate and multiple logistic regression models of associated risk factors for seropositivity of IgG anti-T. gondii antibodies in homeless persons. 


\section{T. gondii}

Risk Factor

Total Positive Negative $p$-value OR

1. Demographic profile

N \% of total N \% of line $\mathbf{N} \%$ of line

\begin{tabular}{|c|c|c|c|c|c|c|c|c|c|}
\hline \multirow[t]{2}{*}{$\overline{\text { Sex }}$} & Male & 107 & 89.2 & 41 & 38.3 & 66 & 61.7 & 0.282 & $0.48(0.12-1.85)$ \\
\hline & Female & 13 & 10.8 & 3 & 23.1 & 10 & 76.9 & & \\
\hline \multirow[t]{2}{*}{ Marital Status } & Unmarried & 108 & 90.0 & 41 & 38.0 & 67 & 62.0 & 0.377 & $0.54(0.13-2.12)$ \\
\hline & Accompanied & 12 & 10.0 & 3 & 25.0 & 9 & 75.0 & & \\
\hline \multirow[t]{2}{*}{ Racial self-declaration } & White & 28 & 23.3 & 8 & 28.6 & 20 & 71.4 & 0.310 & $1.60(0.64-4.03)$ \\
\hline & Non-white & 92 & 76.7 & 36 & 39.1 & 56 & 60.9 & & \\
\hline \multirow[t]{2}{*}{ Educational background } & None to 8th grade & 91 & 75.8 & 34 & 37.4 & 57 & 62.6 & 0.438 & $0.72(0.32-1.64)$ \\
\hline & High School and University & 29 & 24.2 & 9 & 31.0 & 20 & 69.0 & & \\
\hline \multirow[t]{2}{*}{ Income } & No income & 99 & 84.6 & 37 & 37.0 & 63 & 63.0 & 0.879 & $1.08(0.38-3.03)$ \\
\hline & With income & 18 & 15.4 & 7 & 38.9 & 11 & 61.1 & & \\
\hline \multirow[t]{2}{*}{ City of origin } & São Paulo city & 38 & 32.2 & 12 & 31.6 & 26 & 68.4 & 0.404 & $1.41(0.62-3.02)$ \\
\hline & Other cities & 80 & 67.8 & 32 & 39.5 & 49 & 60.5 & & \\
\hline \multirow[t]{2}{*}{ Travel to other cities } & Yes & 23 & 20.2 & 33 & 36.3 & 58 & 63.7 & 0.799 & $1.13(0.44-2.89)$ \\
\hline & No & 91 & 79.8 & 9 & 39.1 & 14 & 60.9 & & \\
\hline \multicolumn{10}{|l|}{ 2. Social profile } \\
\hline \multirow[t]{2}{*}{ Contact with family } & Yes & 66 & 55.9 & 23 & 34.8 & 43 & 65.2 & 0.582 & $1.22(0.58-2.59)$ \\
\hline & No & 52 & 44.1 & 21 & 39.6 & 32 & 60.4 & & \\
\hline \multirow[t]{5}{*}{ Causes for becoming homeless } & Alcohol and drugs & 28 & 23.3 & 9 & 32.1 & 19 & 67.9 & 0.736 & $1.16(0.47-2.89)$ \\
\hline & Family conflicts & 48 & 40.0 & 19 & 39.6 & 29 & 60.4 & 0.360 & $0.69(0.32-1.51)$ \\
\hline & Housing loss & 13 & 10.8 & 3 & 23.1 & 10 & 76.9 & 0.347 & $1.89(0.49-7.33)$ \\
\hline & Other & 18 & 15.0 & 9 & 50.0 & 9 & 50.0 & 0.140 & $0.47(0.17-1.30)$ \\
\hline & Unemployment & 34 & 28.3 & 10 & 29.4 & 24 & 70.6 & 0.433 & $1.41(0.59-3.35)$ \\
\hline \multirow[t]{3}{*}{ Resting place } & Hostel & 68 & 45.3 & 26 & 38.2 & 42 & 61.8 & 0.683 & $0.85(0.40-1.81)$ \\
\hline & Street & 52 & 34.7 & 18 & 34.6 & 34 & 65.4 & 0.905 & $1.05(0.43-2.54)$ \\
\hline & Occupancy & 30 & 20 & 10 & 33.3 & 20 & 66.7 & 0.662 & $1.21(0.50-2.90)$ \\
\hline \multirow[t]{2}{*}{ Pregnant woman } & Yes & 2 & 1.7 & 0 & 0.0 & 2 & 100.0 & 0.278 & $*$ \\
\hline & No & 118 & 98.3 & 44 & 37.3 & 74 & 62.7 & & \\
\hline \multirow[t]{2}{*}{ Have children } & Yes & 81 & 67.5 & 33 & 40.7 & 48 & 59.3 & 0.182 & $0.57(0.25-1.30)$ \\
\hline & No & 39 & 32.5 & 11 & 28.2 & 28 & 71.8 & & \\
\hline \multirow[t]{2}{*}{ Have own children } & Live together & 4 & 5.1 & 0 & 0.0 & 4 & 100.0 & 0.087 & $*$ \\
\hline & Other people & 74 & 94.9 & 32 & 43.2 & 42 & 56.8 & & \\
\hline \multirow[t]{2}{*}{ Live alone } & Yes & 52 & 46.0 & 19 & 36.5 & 33 & 63.5 & 0.815 & $0.91(0.42-1.97)$ \\
\hline & No & 61 & 54.0 & 21 & 34.4 & 40 & 65.6 & & \\
\hline \multirow[t]{2}{*}{ Pet owner } & Yes & 26 & 22.4 & 12 & 46.2 & 14 & 53.8 & 0.231 & $0.58(0.24-1.41)$ \\
\hline & No & 90 & 77.6 & 30 & 33.3 & 60 & 66.7 & & \\
\hline \multirow[t]{2}{*}{ Dog owner } & Yes & 21 & 18.1 & 11 & 52.4 & 10 & 47.6 & 0.088 & $0.44(0.16-1.14)$ \\
\hline & No & 95 & 81.9 & 31 & 32.6 & 64 & 67.4 & & \\
\hline Cat owner & Yes & 6 & 5.2 & 2 & 33.3 & 4 & 66.7 & 0.880 & $1.14(0.20-6.52)$ \\
\hline & No & 110 & 94.8 & 40 & 36.4 & 70 & 63.6 & & \\
\hline Use of licit and/or illicit drugs & Yes & 91 & 75.8 & 35 & 38.5 & 56 & 61.5 & 0.470 & $0.72(0.29-1.75)$ \\
\hline & No & 29 & 24.2 & 9 & 31.0 & 20 & 69.0 & & \\
\hline Alcohol consumption & Yes & 52 & 43.3 & 18 & 34.6 & 34 & 65.4 & 0.471 & $0.76(0.36-1.60)$ \\
\hline Tobacco use & Yes & 32 & 26.7 & 16 & 50.0 & 16 & 50.0 & 0.068 & $0.46(0.20-1.06)$ \\
\hline Marijuana use & Yes & 31 & 25.8 & 12 & 38.7 & 19 & 61.3 & 0.784 & $0.88(0.38-2.06)$ \\
\hline Cocaine use & Yes & 34 & 28.3 & 12 & 35.3 & 22 & 64.7 & 0.844 & $1.08(0.47-2.48)$ \\
\hline Crack use & Yes & 16 & 13.3 & 7 & 43.8 & 9 & 56.2 & 0.528 & $0.71(0.24-2.06)$ \\
\hline Other drugs & Yes & 5 & 4.2 & 3 & 60.0 & 2 & 40.0 & 0.269 & $0.36\left(\begin{array}{ll}0 & 05-2.30\end{array}\right)$ \\
\hline Assistance by Psychosocial Care Centers (CAPS) & Yes & 31 & 25.8 & 10 & 32.3 & 21 & 67.7 & 0.554 & $1.29(0.54-3.08)$ \\
\hline & No & 89 & 74.2 & 34 & 38.2 & 55 & 61.8 & & \\
\hline 3. Hygiene profile & & & & & & & & & \\
\hline Bath frequency & Daily & 99 & 82.5 & 34 & 34.3 & 65 & 65.7 & 0.252 & $1.73(0.67-4.50)$ \\
\hline & Sporadic & 21 & 17.5 & 10 & 47.6 & 11 & 52.4 & & \\
\hline Wash clothes & Yes & 82 & 69.5 & 30 & 36.6 & 52 & 63.4 & 0.978 & $1.01(0.45-2.24)$ \\
\hline & No & 36 & 30.5 & 14 & 36.8 & 24 & 63.2 & & \\
\hline
\end{tabular}

Page $11 / 12$ 


\begin{tabular}{|c|c|c|c|c|c|c|c|c|c|}
\hline \multirow[t]{2}{*}{ Change clothes frequency } & Daily & 50 & 42.7 & 17 & 34.0 & 33 & 66.0 & \multirow[t]{2}{*}{0.838} & \multirow[t]{2}{*}{$1.08(0.50-2.33)$} \\
\hline & Sporadic & 67 & 57.3 & 24 & 35.8 & 43 & 64.2 & & \\
\hline \multirow[t]{2}{*}{ Body lice bite } & Yes & 63 & 59.4 & 23 & 36.5 & 40 & 63.5 & \multirow[t]{2}{*}{0.752} & \multirow[t]{2}{*}{$1.13(0.51-2.52)$} \\
\hline & No & 43 & 40.6 & 17 & 39.5 & 26 & 60.5 & & \\
\hline \multirow[t]{2}{*}{ Presence of body lice } & Yes & 17 & 14.2 & 4 & 23.5 & 13 & 76.5 & \multirow[t]{2}{*}{0.225} & \multirow[t]{2}{*}{$2.06(0.62-6.77)$} \\
\hline & No & 103 & 85.8 & 40 & 38.8 & 63 & 61.2 & & \\
\hline
\end{tabular}

*The percentages can go higher than $100 \%$ because individuals could answer more than one option.

Table 2: Average, median and standard deviation (SD) of $T$. gondii positive and negative homeless persons according to age (years), homelessness time (months), number of children, number of dogs, number of cats, packed cell volume (PCV), total plasma protein (TTP).

\begin{tabular}{lllllllll}
\hline \multirow{2}{*}{$\begin{array}{l}\text { Jndii } \\
\text { Factor }\end{array}$} & \multicolumn{1}{l}{ Negative } & \multicolumn{3}{l}{ Positive } & & \multirow{2}{*}{$p$-value } \\
\cline { 2 - 7 } & 43.55 & 44.50 & 14.0341 .18 & 42.50 & 11.96 & 0.412 \\
(years) & 2.19 & 1.00 & 4.02 & 2.07 & 2.00 & 2.08 & 0.385 \\
elessness time (months) 67.68 & 36.00 & 78.4385 .10 & 36.00 & 103.600 .557 \\
ber of children & 0.34 & 0.00 & 1.27 & 0.62 & 0.00 & 1.40 & 0.081 \\
ber of dogs & 0.05 & 0.00 & 0.23 & 0.17 & 0.00 & 0.82 & 0.928 \\
ber of cats & 42.46 & 42.00 & 4.00 & 42.84 & 44.00 & 4.40 & 0.629 \\
& 7.65 & 7.60 & 0.63 & 7.64 & 7.60 & 0.52 & 0.918 \\
\hline
\end{tabular}

SD, standard deviation; PCV, packed cell volume; TTP, total plasma protein.

\section{Supplementary Information}

Additional file 1: S1 Dataset. Data source, risk factors of demographic, social and hygiene profile and serological results for $T$. gondii the HIV inhomeless persons.

\section{Supplementary Files}

This is a list of supplementary files associated with this preprint. Click to download.

- S1File.xlsx 